\title{
The Iowa Gambling Task (IGT) in Brazil: a systematic review
}

\author{
O Iowa Gambling Task (IGT) no Brasil: uma revisão sistemática
}

\author{
André Rutz, ${ }^{1}$ Amer Cavalheiro Hamdan, ${ }^{2}$ Melissa Lamar ${ }^{3}$
}

\begin{abstract}
Background: Decision-making is a complex, multidimensional cognitive function that requires the choice between two or more options and also the predictive analysis of its consequences. One of the tools most widely used to assess decision-making in neuropsychological research is the Iowa Gambling Task (IGT).

Objective: To conduct a systematic review of articles reporting empirical IGT studies based in Brazil.

Method: Articles were obtained from multiple journal databases including ISI Web of Knowledge, Scopus, SciELO, LILACS, and Scholar Google.

Results: Thirty-six studies were included in this review and divided into four categories according to main subject matter (psychiatry \& personality; demographic \& cultural variables; medical/clinic; and psychometric properties \& test administration standardization). In general, there was a significant growth in research employing IGT $\left(\chi^{2}=17.6, \mathrm{df}=5, \mathrm{p}=0.0003\right)$, but this growth was restricted to a few geographic areas of Brazil. The psychiatry \& personality subject matter was the most abundant, accounting for 14 publications (39\% of the total sample).

Conclusion: Since its first adaptation to Brazilian Portuguese in 2006, a growing interest in decision-making as measured by the IGT can be observed, with psychiatry \& personality topics representing a large portion of the scientific inquiry to date. Nevertheless, in order to extend the initial results of Brazilian IGT decision-making research, more studies are necessary - across a more diverse range of topics, including demographic \& cultural variables, and psychometric properties \& test administration standardization, the areas least studied - , as is the dissemination of the IGT to more regions of the country.

Keywords: Neuropsychological tests, systematic review, Iowa Gambling Task, decision-making.
\end{abstract}

\begin{abstract}
Resumo
Contexto: A tomada de decisão é uma função cognitiva complexa e multidimensional que envolve a escolha entre duas ou mais opções, bem como a análise preditiva das suas consequências. Um dos instrumentos de pesquisa mais amplamente utilizados para avaliar a tomada de decisão em neurociência é o Iowa Gambling Task (IGT).

Objetivo: Realizar uma revisão sistemática de artigos empíricos conduzidos com o IGT no Brasil.

Método: Os artigos foram obtidos através de busca nos bancos de dados ISI Web of Knowledge, Scopus, SciELO, LILACS e Scholar Google.

Resultados: Trinta e seis estudos foram incluídos e divididos em quatro categorias de acordo com o tema principal (variáveis demográficas e culturais; psiquiatria e personalidade; variáveis médico-genéticas e saúde geral; e propriedades psicométricas e padronização de aplicação). Em geral, houve um crescimento significativo da pesquisa utilizando o IGT $\left(\chi^{2}=17,6, \mathrm{gl}=5, \mathrm{p}=\right.$ 0,0003 ), porém restrito a algumas áreas geográficas brasileiras. O eixo temático de psiquiatria e personalidade foi o que mais produziu estudos, contabilizando 14 publicações (39\% da amostra total).

Conclusão: Desde sua primeira adaptação para o português brasileiro em 2006, pode-se observar um crescente interesse pela tomada de decisão medida pelo IGT, sendo assuntos relacionados ao tema psiquiatria e personalidade responsáveis por grande parte dos estudos realizados até o momento. No entanto, para ampliar os resultados iniciais da pesquisa nacional com o IGT, mais estudos são necessários - com uma amplitude maior de áreas temáticas, incluindo as categorias menos estudadas até o momento: variáveis demográficas e culturais e propriedades psicométricas e padronização de aplicação - bem como uma maior disseminação do IGT em outros centros regionais do país. Descritores: Testes neuropsicológicos, revisão sistemática, Iowa Gambling Task, tomada de decisão.
\end{abstract}

\footnotetext{
${ }^{1}$ Psychologist. Master's Program in Psychology, Universidade Federal do Paraná (UFPR), Curitiba, PR, Brazil. ${ }^{2}$ Professor, Department of Psychology, UFPR, Curitiba, PR, Brazil. ${ }^{3}$ Associate professor, Department of Psychiatry, University of Illinois, Chicago, IL, USA.

Financial support: none.

Submitted Jan 31 2013, accepted for publication May 31 2013. No conflicts of interest declared concerning the publication of this article.

Suggested citation: Rutz A, Hamdan AC, Lamar M. The Iowa Gambling Task (IGT) in Brazil: a systematic review. Trends Psychiatry Psychother. 2013;35(3):160-70.
} 


\section{Introduction}

Decision-making can be defined as a complex, multidimensional cognitive function that involves choosing between two or more options. ${ }^{1,2}$ The Iowa Gambling Task (IGT) is an instrument designed to evaluate decisionmaking in a manner similar to real-life circumstances. It simulates the uncertainty of rewards and punishments by presenting a choice between small rewards/small punishments vs. sporadic larger rewards and even larger punishments. The IGT is considered the international gold standard in the assessment of decision-making, ${ }^{3}$ deriving much of its brain-behavior associations from human lesion and neuroimaging studies. ${ }^{4,5}$ These studies suggest that the IGT requires prefrontal structure (i.e., ventromedial/ orbitofrontal) and function (i.e., executive functions such as impulse inhibition and reward processing), in addition to other neural correlates, such as the cerebellum and basal ganglia.

The IGT was created in 1994 by Bechara et al. ${ }^{4}$ at the Spence Laboratory, Department of Psychology and Neuroscience, University of Iowa, Des Moines, USA. It was originally designed to test the somatic marker hypothesis, formulated by Damasio et al. ${ }^{5}$ According to this hypothesis, making decisions would involve the activation of a complex network of body signals (known as somatic markers) that integrate emotion and reason. Determined in great part by learning from previously chosen outcomes, somatic markers such as the "gut feeling" implied in emotions that arise in betting decisions, for example, are the integration of body states directly linked to visceral sensations, i.e., physiological sensations that add the emotional weight necessary to make a decision viable in situations with a high degree of uncertainty and complexity. Thus, somatic markers influence behavior by modulating reasoning within an emotional context to prompt a choice.

While it can be administered by hand, IGT application is typically computerized. It consists of a 'gambling' game in which the participant is asked to choose a card from 1 of 4 decks of cards ( $, B, C$, or D) for a total of 100 trials. For every choice made, the participant is awarded a cash value that varies in magnitude according to the chosen deck, but it may also be combined with a punishment in the form of monetary loss deducted from the amount of money accumulated over the course of the task. Two decks (A\&B) are initially more attractive because of the high initial gains, but they also cause large monetary losses. The other two decks (C\&D) offer modest rewards and losses in the immediate term but are more advantageous over time because they do not cause the losses of the other decks. Thus, the most advantageous strategy in the IGT is to avoid riskier decks (A\&B) and prefer the more mundane albeit consistent ones (C\&D).
The participant's decision-making profile is rendered by a net score (total choices of decks C\&D minus total choices of decks A\&B) that implies either advantageous (positive net score) or disadvantageous (negative net score) decision-making. Additionally, performance may be analyzed using a block of 20 cards to assess strategy learning over time. Some authors ${ }^{6}$ argue that decisionmaking as measured by the IGT comprises three different components: motivation to gain and to ignore losses; learning rate; and attention to recent outcomes/ response sensitivity.

Across neurological and neuropsychiatric studies, ${ }^{4}$ decision-making measured by the IGT has been shown to differ according to psychiatric diagnosis. For example, impairments in impulsivity and reward processing in decision-making were identified in different types of psychiatric disorders: attention deficit hyperactivity disorder (ADHD), ${ }^{3,7}$ bipolar disorder (BD),,$^{8-10}$ obsessive-compulsive disorder (OCD), ${ }^{11-14}$ drug and alcohol abuse, ${ }^{15-18}$ internet abuse, ${ }^{19}$ pathological gambling, borderline personality disorder, ${ }^{20}$ patients with a suicide attempt history, ${ }^{8,9}$ post-traumatic stress disorder (PTSD), ${ }^{12}$ and generalized anxiety disorder (GAD). ${ }^{10}$ In addition, the incorporation of genetics to IGT-based investigations of these psychiatric diagnoses has shown promising results for a better understanding of the biological substrates of social behavior, e.g., the association between genotypes and impulsivity (5-HTTLPR polymorphism) $)^{21}$ and analysis of the brainderived neurotrophic factor (BDNF) gene. ${ }^{14}$

In addition to the expansion of decision-making research with neologisms such as "decision neuroscience," international adaptations, including those conducted in Brazil, have allowed to extend this work across languages, countries, and continents. The IGT was adapted to Brazilian Portuguese by two distinct research groups: one from Universidade Federal do Rio Grande do Sul (UFRGS), ${ }^{1}$ southern Brazil, in 2006, and the other by Universidade Federal de Minas Gerais (UFMG), ${ }^{3}$ southeastern Brazil, in 2008. This has led to the creation of two regionalized versions of the IGT, with minor linguistic differences in the instructions but a common reward schedule identical to that of the original task. Both research groups stated that their test adaptations were developed in close partnership with the author of the original test. ${ }^{4}$

The aim of this study was to conduct a systematic review of empirical research conducted with IGT in Brazil. This article summarizes some of the key topics of research on decision-making and aims to provide the reader with a brief overview of the current state of scientific debate in Brazil as it relates to the IGT. Plus, it intends to discuss possible directions for future research. 


\section{Methods}

\section{Search strategy}

The first studies surveyed were identified on the ISI Web of Science, Scopus, LILACS, and SciELO databases using the following descriptors: ["IGT" and "Brazil"] or ["IGT" and "Brasil"] or ["Iowa Gambling Task" and "Brasil"]. Thirteen studies were initially identified. From this starting point, a reverse search was performed in the references of the selected articles to locate further empirical studies that had not been pinpointed by the initial survey. Another survey was conducted in Google Scholar using the keywords ["Iowa Gambling Task" and "Brazil"], and the links for the first 10 result pages were manually inspected, adding another 17 studies. As a result, a total of 30 studies were selected using the three survey methods.

The next step was to browse for other publications by the first authors of each of the 30 articles on the Scopus database and the Lattes platform, to ensure that other studies by the same authors using the IGT would not be overlooked. With this procedure, two additional articles were located ( $n=32$ ). Finally, the two research groups responsible for the adaptation of the IGT to Brazil were

Table 1 - Empirical IGT empirical studies conducted in Brazil: descriptive data

\begin{tabular}{|c|c|c|c|c|c|}
\hline Author (year) & Samples (N) & $\begin{array}{l}\text { Gender } \\
\text { (M/F) }\end{array}$ & Age & Control & Education (years) \\
\hline $\begin{array}{l}\text { Schneider et al. } \\
\qquad(2006)^{1}\end{array}$ & $\begin{array}{l}n=82 \\
\text { adults: } 42 \\
\text { elderly: } 40\end{array}$ & $27 / 55$ & $\begin{array}{l}\text { adults: } 24 \pm 4.43 \\
\text { elderly: } 68 \pm 5.01\end{array}$ & Yes & $\begin{array}{l}\text { high school (incomplete): } n=10 \\
\text { graduation (incomplete) } n=30 \\
\text { graduation (complete): } n=42\end{array}$ \\
\hline $\begin{array}{l}\text { Leite et al. } \\
(2007)^{23}\end{array}$ & $\begin{array}{c}n=11 \\
\text { ACo } A \text { adults: } 1 \\
\text { controls: } 10\end{array}$ & $11 /-$ & $\begin{array}{l}\text { ACoA adults: } 45 \text { years } \\
\text { controls: match }\end{array}$ & Yes & $\begin{array}{l}\text { ACoA adults: - } \\
\text { controls: match }\end{array}$ \\
\hline $\begin{array}{l}\text { Malloy-Diniz et } \\
\text { al. }(2007)^{7}\end{array}$ & $\begin{array}{l}n=101 \\
\text { ADHD adults: } 50 \\
\text { controls: } 51\end{array}$ & $48 / 53$ & $\begin{array}{l}\text { ADHD adults: } 33.7 \pm 11.7 \\
\text { controls: } 32.2 \pm 12.9\end{array}$ & Yes & $\begin{array}{l}\text { ADHD adults: } 12.95 \pm 2.1 \\
\text { controls: } 13.27 \pm 2.4\end{array}$ \\
\hline $\begin{array}{l}\text { Schneider et al. } \\
\qquad(2007)^{24}\end{array}$ & $n=97$ & $35 / 62$ & $\begin{array}{l}\text { elderly group I: } 69.68 \pm 8.27 \\
\text { elderly group II: } 70.59 \pm 8.16 \\
\text { elderly group III: } 68.60 \pm 5.02\end{array}$ & Yes & $\begin{array}{l}\text { group I: } 15.52 \pm 2.85 \\
\text { group II: } 14.94 \pm 5.54 \\
\text { group III: } 13.80 \pm 2.98\end{array}$ \\
\hline $\begin{array}{l}\text { Bakos et al. } \\
(2008)^{25}\end{array}$ & $\begin{array}{l}n=20 \\
\text { elderly group I: } 10 \\
\text { elderly group II: } 10\end{array}$ & $2 / 18$ & $\begin{array}{l}\text { elderly group I: } 62 \pm 2.1 \\
\text { elderly group II: } 79.6 \pm 3.3\end{array}$ & Yes & $14.05 \pm 2.5$ \\
\hline $\begin{array}{l}\text { Malloy-Diniz et } \\
\text { al. }(2008)^{3}\end{array}$ & $\begin{array}{l}\mathrm{n}=75 \\
\text { non-English proficient } \\
\text { adults: } 25 \\
\text { English fluent adults: } 25 \\
\text { ADHD adults: } 25\end{array}$ & $33 / 42$ & $\begin{array}{l}\text { non-English proficient adults: } \\
\quad 32.1 \pm 8.5 \\
\text { English fluent adults: } 28.5 \pm 6.5 \\
\text { ADHD adults: } 31.8 \pm 9.1\end{array}$ & Yes & $\begin{array}{l}\text { non-English proficient adults: } \\
13.9 \pm 2.3 \\
\text { English fluent adults: } 13 \pm 2.2 \\
\text { ADHD adults: } 13.3 \pm 2.4\end{array}$ \\
\hline $\begin{array}{l}\text { Rocha et al. } \\
(2008)^{20}\end{array}$ & $\mathrm{n}=1$ & $1 /-$ & adult: 27 years & No & 7 years \\
\hline $\begin{array}{l}\text { Rocha et al. } \\
(2008)^{11}\end{array}$ & $\begin{array}{c}n=49 \\
\text { OCD adults: } 49\end{array}$ & $23 / 26$ & $\begin{array}{c}\text { OCD adults group I: } \\
29.44 \pm 13.68 \\
\text { OCD adults group II: } \\
31.19 \pm 12.10\end{array}$ & Yes & $\begin{array}{l}\text { adults group I: } 11.74 \pm 5.21 \\
\text { adults group II: } 10.85 \pm 5.30\end{array}$ \\
\hline $\begin{array}{l}\text { Salgado et al. } \\
\qquad(2008)^{15}\end{array}$ & $\begin{array}{l}\quad \mathrm{n}=61 \\
\text { alcohol-dependent adults: } 31 \\
\text { healthy adults: } 30\end{array}$ & $46 / 15$ & $\begin{array}{l}\text { alcohol-dependent adults: } \\
49.97 \pm 6.1 \\
\text { healthy adults: } 46.93 \pm 8.3\end{array}$ & Yes & $\begin{array}{c}\text { alcohol-dependent adults: } \\
10.55 \pm 2.6 \\
\text { healthy adults: } 11.07 \pm 4.0\end{array}$ \\
\hline $\begin{array}{l}\text { Malloy-Diniz et } \\
\quad \text { al. }(2009)^{8}\end{array}$ & $\begin{array}{c}\mathrm{n}=92 \\
\text { BPI adults: } 39 \\
\text { healthy adults: } 53\end{array}$ & $34 / 58$ & $\begin{array}{l}\text { BPI adults: } 40.9 \pm 13.0 \\
\text { healthy adults: } 36.9 \pm 9.8\end{array}$ & Yes & $\begin{array}{l}\text { BPI adults: } 48.7 \% \text { high school } \\
\text { (complete) } \\
\text { healthy adults: } 52.8 \% \text { high school } \\
\text { (complete) }\end{array}$ \\
\hline $\begin{array}{l}\text { Wagner et al. } \\
\qquad(2009)^{26}\end{array}$ & $\begin{array}{c}n=37 \\
\text { MCI elderly: } 10 \\
\text { non-MCI elderly: } 27\end{array}$ & $4 / 33$ & $\begin{array}{c}\text { MCI elderly: } 70.2 \pm 6.3 \\
\text { non-MCI elderly: } 69.6 \pm 6.2\end{array}$ & Yes & $\begin{array}{c}\text { MCI elderly: } 9.2 \pm 4.6 \\
\text { non-MCI elderly: } 10.4 \pm 5.3\end{array}$ \\
\hline $\begin{array}{l}\text { Wagner et al. } \\
\qquad(2009)^{27}\end{array}$ & $\begin{array}{l}\quad n=44 \\
\text { elderly group I: } 27 \\
\text { elderly group II: } 17\end{array}$ & $3 / 41$ & $\begin{array}{l}\text { elderly group I: } 69.6 \pm 6.2 \\
\text { elderly group II: } 70.59 \pm 8.15\end{array}$ & Yes & $\begin{array}{l}\text { elderly group I: } 10.4 \pm 5.3 \\
\text { elderly group II: } 14.91 \pm 5.53\end{array}$ \\
\hline $\begin{array}{l}\text { Bakos et al. } \\
(2010)^{28}\end{array}$ & $\begin{array}{l}n=72 \\
\text { adults: } 36 \\
\text { elderly: } 36\end{array}$ & $19 / 53$ & $\begin{array}{l}\text { adults: } 29.86 \pm 4.63 \\
\text { elderly: } 66.89 \pm 5.19\end{array}$ & Yes & $\begin{array}{l}\text { adults: } 14.69 \pm 2.81 \\
\text { elderly: } 12.75 \pm 3.39\end{array}$ \\
\hline $\begin{array}{l}\text { Bakos et al. } \\
\quad(2010)^{29}\end{array}$ & $\begin{array}{l}\quad n=70 \\
\text { Brazilians (adults: } 10, \\
\text { elderly: } 25) \\
\text { Americans (adults: } 10, \\
\text { elderly: } 25 \text { ) }\end{array}$ & $18 / 52$ & $\begin{array}{l}\text { BA: } 32.35 \pm 3.72 \\
\text { BE: } 68.16 \pm 5.40 \\
\text { AA: } 32.35 \pm 3.72 \\
\text { AE: } 68.16 \pm 5.40\end{array}$ & Yes & $\begin{array}{l}\text { BA: } 16.05 \pm 2.42 \\
\text { BE: } 13.98 \pm 2.97 \\
\text { AA: } 16.05 \pm 2.42 \\
\text { AE: } 13.98 \pm 2.97\end{array}$ \\
\hline $\begin{array}{l}\text { Borges et al. } \\
(2010)^{30}\end{array}$ & $\begin{array}{l}\mathrm{n}=3 \\
\text { young: } 1 \\
\text { adults: } 2\end{array}$ & $1 / 2$ & $\begin{array}{c}\text { young: } 19 \text { years } \\
\text { women: } 34 \text { years } \\
\text { men: } 29 \text { years }\end{array}$ & No & $\begin{array}{c}\text { young: graduation (incomplete) } \\
\text { women: graduation (complete) } \\
\text { men: graduation (complete) }\end{array}$ \\
\hline $\begin{array}{l}\text { Cardoso et al. } \\
\quad(2010)^{31}\end{array}$ & $\mathrm{n}=50$ & $15 / 35$ & adults: $36.50 \pm 19.55$ & No & adults: $14.34 \pm 3.92$ \\
\hline $\begin{array}{l}\text { Coutinho et al. } \\
(2010)^{19}\end{array}$ & $n=2$ & $2 /-$ & $\begin{array}{l}\text { young I: } 16 \text { years } \\
\text { young II: } 19 \text { years }\end{array}$ & No & 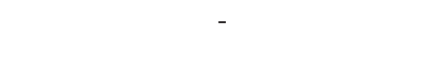 \\
\hline $\begin{array}{l}\text { Borges et al. } \\
(2011)^{12}\end{array}$ & $\begin{array}{l}\mathrm{n}=118 \\
\text { post-traumatic OCD: } 16 \\
\text { pre-traumatic OCD: } 18 \\
\text { non-traumatic OCD: } 67 \\
\text { controls: } 17\end{array}$ & $47 / 71$ & $\begin{array}{c}\text { post-traumatic OCD: } 39.2 \pm 12.4 \\
\text { pre-traumatic OCD: } 41.2 \pm 12.3 \\
\text { non-traumatic OCD: } 33.0 \pm 13.2 \\
\text { controls: } 29.9 \pm 7.9\end{array}$ & Yes & $\begin{array}{c}\text { post-traumatic OCD: } 11.6 \pm 4.2 \\
\text { pre-traumatic OCD: } 13.6 \pm 4.3 \\
\text { non-traumatic OCD: } 13.1 \pm 3.4 \\
\text { Controls: } 14.0 \pm 2.7\end{array}$ \\
\hline
\end{tabular}


contacted, and the principal investigators were asked to review our list of 32 studies for possible omissions. Both groups made additions to the list: the UFRGS group added three studies, and the UFMG one $(n=36)$. We are fairly confident that our final sample of 36 studies represents all empirical IGT studies conducted in Brazil from March 2006 to June 2012.

\section{Inclusion and exclusion criteria}

Any Brazilian empirical IGT study employing IGT alone or combined with other instruments was included in our review. Theoretical studies, literature reviews, letters to the editor, dissertational studies, and unpublished doctoral theses were excluded. As the studies were included in the sample, they were assigned a topic category and subjected to data inspection and analysis.

\section{Data extraction and analysis}

Descriptive data of the studies included are presented in Table 1. To ensure greater accuracy, data inspection and extraction were performed by one reviewer and checked by a second one, blind to the results of this study.

Table 1 - Empirical IGT empirical studies conducted in Brazil: descriptive data (cont.)

\begin{tabular}{|c|c|c|c|c|c|}
\hline Author (year) & Samples (N) & $\begin{array}{l}\text { Gender } \\
\text { (M/F) }\end{array}$ & Age & Control & Education (years) \\
\hline $\begin{array}{l}\text { Cunha et al. } \\
(2011)^{16}\end{array}$ & $\begin{array}{c}\mathrm{n}=30 \\
\text { drug-dependent adults: } 15 \\
\text { controls: } 15\end{array}$ & $30 /-$ & $\begin{array}{c}\text { drug-dependent adults: } \\
25.67 \pm 6.53 \\
\text { controls: } 26.60 \pm 6.62\end{array}$ & Yes & $\begin{array}{c}\text { drug-dependent adults: } \\
11.20 \pm 1.66 \\
\text { controls: } 10.53 \pm 2.36\end{array}$ \\
\hline $\begin{array}{l}\text { Fernandes et al. } \\
(2011)^{32}\end{array}$ & $\begin{array}{c}n=267 \\
\text { subclinical hypothyroidism } \\
\text { adults: } 89 \\
\text { controls: } 178\end{array}$ & $48 / 219$ & $\begin{array}{c}\text { subclinical hypothyroidism } \\
\text { adults: } 35.40 \pm 14.12 \\
\text { controls: } 33.34 \pm 13.22\end{array}$ & Yes & $\begin{array}{c}\text { subclinical hypothyroidism adults: } \\
9.56 \pm 4.87 \\
\text { controls: } 9.26 \pm 5.28\end{array}$ \\
\hline $\begin{array}{l}\text { Gois et al. } \\
(2011)^{33}\end{array}$ & $\begin{array}{c}n=73 \\
\text { temporal lobe epilepsy } \\
\text { adults: } 35 \\
\text { controls: } 38\end{array}$ & $34 / 39$ & $\begin{array}{c}\text { temporal lobe epilepsy adults: } \\
\text { 39.82 } \pm 9.05 \\
\text { controls: } 28.61 \pm 9.00\end{array}$ & Yes & - \\
\hline $\begin{array}{l}\text { Gonçalves et al. } \\
(2011)^{17}\end{array}$ & $n=1$ & $1 /-$ & adult: 30 years & No & high school (complete) \\
\hline $\begin{array}{l}\text { Lage et al. } \\
(2011)^{21}\end{array}$ & $\mathrm{n}=127$ & $52 / 75$ & adults: $29.5 \pm 11.8$ & Yes & $\begin{array}{l}\text { graduation (incomplete): } n=86 \\
\text { graduation (complete): } n=41\end{array}$ \\
\hline $\begin{array}{l}\text { Lage et al. } \\
(2011)^{34}\end{array}$ & $\mathrm{n}=22$ & $9 / 13$ & adults: $22.5 \pm 4.2$ & No & graduation (incomplete): $n=22$ \\
\hline $\begin{array}{l}\text { Lage et al. } \\
(2011)^{35}\end{array}$ & $\begin{array}{c}n=11 \\
\text { youngsters: } 11\end{array}$ & $-/ 11$ & youngsters: $17.45 \pm 0.5$ & No & - \\
\hline $\begin{array}{l}\text { Rocha et al. } \\
(2011)^{13}\end{array}$ & $\begin{array}{c}n=214 \\
\text { OCD adults: } 107 \\
\text { controls: } 107\end{array}$ & $114 / 100$ & $\begin{array}{c}\text { OCD adults: } 28.40 \pm 14.12 \\
\text { controls: } 29.33 \pm 13.22\end{array}$ & Yes & $\begin{array}{l}\text { OCD adults: } 10.87 \pm 4.75 \\
\text { controls: } 10.26 \pm 5.02\end{array}$ \\
\hline $\begin{array}{l}\text { Rocha et al. } \\
(2011)^{14}\end{array}$ & $\begin{array}{c}n=122 \\
\text { OCD \& Met-allele adults: } 40 \\
\text { OCD \& non-Met-allele } \\
\text { adults: } 82\end{array}$ & $65 / 57$ & $\begin{array}{c}\text { OCD \& Met-allele: } 28.40 \pm 14.12 \\
\text { OCD \& non-Met-allele: } \\
29.33 \pm 13.22\end{array}$ & Yes & OCD \& Met-allele: $10.56 \pm 4.87$ \\
\hline $\begin{array}{l}\text { Carvalho et al. } \\
\qquad(2011)^{36}\end{array}$ & $\begin{array}{l}n=60 \\
\text { low education adults: } 20 \\
\text { high education adults: } 40\end{array}$ & $36 / 24$ & $\begin{array}{c}\text { low education adults: } \\
25.23 \pm 4.63 \\
\text { high education adults: } \\
26.30 \pm 6.40\end{array}$ & Yes & $\begin{array}{l}\text { OCD \& non-Met-allele: } 10.26 \pm 4.90 \\
\text { low education adults: } 15.73 \pm 2.69 \\
\text { high education adults: } 7.45 \pm 0.99\end{array}$ \\
\hline $\begin{array}{l}\text { Scheffer et al. } \\
(2011)^{37}\end{array}$ & $\begin{array}{l}n=19 \\
\text { frontal stroke adults: } 19\end{array}$ & $10 / 9$ & $\begin{array}{c}\text { men: } 60.90 \pm 8.93 \\
\text { women: } 60.44 \pm 11.57\end{array}$ & Yes & $\begin{array}{c}\text { men: } 9.85 \pm 4.46 \\
\text { women: } 11.27 \pm 5.86\end{array}$ \\
\hline $\begin{array}{l}\text { Malloy-Diniz et } \\
\text { al. }(2011)^{9}\end{array}$ & $\begin{array}{c}\mathrm{n}=189 \\
\text { BD adults: } 95 \\
\text { controls: } 94\end{array}$ & $70 / 119$ & $\begin{array}{l}\text { BD adults: } 41 \pm 12 \\
\text { controls: } 32 \pm 13\end{array}$ & Yes & $\begin{array}{l}\text { BD adults: } 46.3 \% \text { graduation level } \\
\text { controls: } 59.6 \% \text { graduation level }\end{array}$ \\
\hline $\begin{array}{l}\text { Cardoso et al. } \\
(2012)^{38}\end{array}$ & $\begin{array}{c}\mathrm{n}=2 \\
\text { right-hemisphere lesion } \\
\text { adult: } 1 \\
\text { left-hemisphere lesion } \\
\text { adult: } 1\end{array}$ & $2 / 0$ & $\begin{array}{l}\text { case I: } 53 \\
\text { case II: } 54\end{array}$ & No & $\begin{array}{l}\text { case I: } 20 \\
\text { case II: } 11\end{array}$ \\
\hline $\begin{array}{l}\text { Viola et al. } \\
(2012)^{18}\end{array}$ & $\begin{array}{c}n=45 \\
\text { crack-dependent adults: } 30 \\
\text { controls: } 15\end{array}$ & $23 / 22$ & $\begin{array}{c}\text { crack-dependent adults: } \\
30.37 \pm 10.06 \\
\text { controls: } 27.20 \pm 7.47\end{array}$ & Yes & $\begin{array}{c}\text { crack-dependent adults: } \\
7.77 \pm 2.28 \\
\text { controls: } 8.47 \pm 2.10\end{array}$ \\
\hline $\begin{array}{l}\text { Carvalho et al. } \\
\qquad(2012)^{39}\end{array}$ & $\begin{array}{c}n=89 \\
\text { group I: } 60 \\
\text { group II: } 29\end{array}$ & $49 / 40$ & $\begin{array}{l}\text { adults group I: } 38.55 \pm 19.84 \\
\text { adults group II: } 25.38 \pm 5.15\end{array}$ & No & $\begin{array}{l}\text { adults group I: } 12.83 \pm 4.42 \\
\text { adults group II: } 12.76 \pm 4.98\end{array}$ \\
\hline $\begin{array}{l}\text { Couto et al. } \\
(2012)^{10}\end{array}$ & $\begin{array}{c}n=95 \\
\text { BD adults: } 41 \\
\text { BD \& GAD adults: } 54\end{array}$ & $30 / 65$ & $\begin{array}{l}\text { BD adults: } 42.71 \pm 12.21 \\
\text { BD \& GAD adults: } 39.59 \pm 12.45\end{array}$ & Yes & $\begin{array}{c}\text { BD adults: high school (complete) } \\
-n=26 \\
\text { BD \& GAD adults: high school } \\
\text { (complete) }-n=38\end{array}$ \\
\hline $\begin{array}{l}\text { Lage et al. } \\
(2012)^{40}\end{array}$ & $\mathrm{n}=81$ & $34 / 47$ & adults: $23.6 \pm 3.8$ & Yes & graduation (incomplete): $\mathrm{n}=81$ \\
\hline $\begin{array}{l}\text { Carvalho et al. } \\
(2012)^{41}\end{array}$ & $\begin{array}{l}n=80 \\
\text { adults: } 40 \\
\text { elderly: } 40\end{array}$ & $28 / 52$ & $\begin{array}{l}\text { adults: } 25.50 \pm 4.70 \\
\text { elderly: } 67.40 \pm 5.02\end{array}$ & Yes & $\begin{array}{l}\text { adults: } 15.74 \pm 2.69 \\
\text { elderly: } 14.68 \pm 2.80\end{array}$ \\
\hline
\end{tabular}

$\overline{\mathrm{AA}}=$ American adults; $\mathrm{ACOA}=$ anterior communicant artery aneurysm; $\mathrm{ADHD}=$ attention deficit hyperactivity disorder; $\mathrm{AE}=\mathrm{American}$ elderly; $\mathrm{BA}=\mathrm{Brazilian}$ adults; $\mathrm{BD}=$ bipolar disorder; $\mathrm{BE}=$ Brazilian elderly; $\mathrm{BPI}=$ bipolar disorder type I; $\mathrm{F}=$ female; GAD = generalized anxiety disorder; IGT = Iowa Gambling Test; $\mathrm{M}=$ male; $\mathrm{MCI}=$ mild cognitive impairment; $\mathrm{OCD}$ = obsessive-compulsive disorder. 


\section{Results}

The 36 empirical studies identified in this systematic review covered a wide range of topics and experimental designs. All selected studies used the IGT: in seven of them $(19 \%)$, the IGT was the only assessment tool employed; in the other $29(81 \%)$, it was part of a neuropsychological assessment battery, i.e., combined with other instruments to assess executive functions. The most frequent association was with the Continuous Performance Task (CPT-II), present in 16 of the 29 studies (55\%). The second most frequent neuropsychological test combined with the IGT was the Wisconsin Card Sorting Test (WCST), mentioned in a total of 12 studies (41\%).

\section{Geographic distribution}

In order to trace the geographic dispersion of IGT studies, we considered the state of origin of the first author's academic affiliation as cited in each paper. Summing up all study locations, four Brazilian states emerged as major centers of IGT research: Minas Gerais (16/36, 44.4\%), Rio Grande do Sul (15/36, 41.7\%), Rio de Janeiro $(3 / 36,8.3 \%)$, and São Paulo (2/36, 5.6\%). Results of the chi-square test indicated a statistically significant difference regarding research productivity according to geographic distribution $\left(\chi^{2}=18.8, \mathrm{df}=3\right.$, $p=0.0003)$, favoring the two first states where IGT adaptation to Brazil was performed.

\section{Chronological distribution}

Concerning publication date, the chi-square test indicated a statistically significant difference regarding the number of publications by year $\left(\chi^{2}=17.6, d f=5, p=0.0035\right)$, with year 2011 showing the majority of Brazilian IGT publications, as shown in Figure 1 (articles published as of

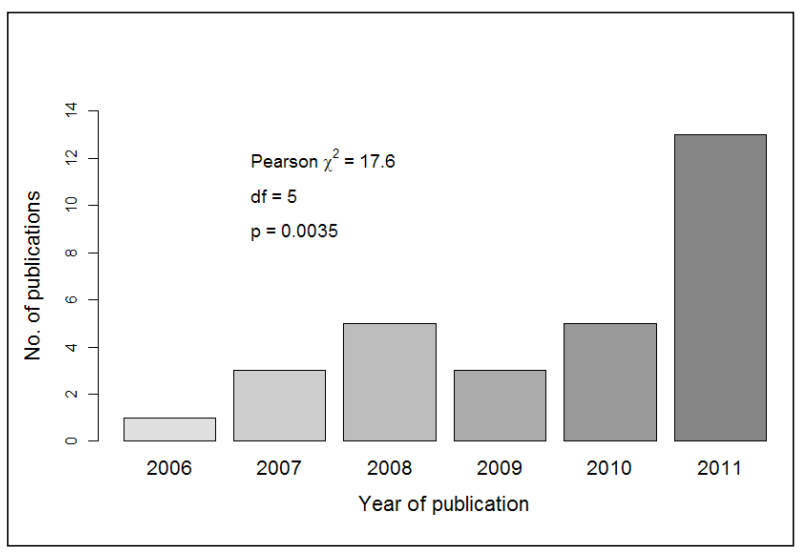

Figure 1 - Evolution of Brazilian publications per year since first adaptation of the IGT to Brazilian Portuguese
2012 were not included in this analysis because the year was not complete at the time of data collection).

\section{Subject matter}

The 36 articles were divided into four subject matter categories, as follows: demographic \& cultural variables; psychiatry \& personality; medical/clinic; and psychometric properties \& test administration standardization. Some articles also addressed issues relative to other categories, but here only the key feature of the study was considered (i.e., the topic most focused on by the authors throughout the paper) to ensure better accuracy and interpretation of statistical data. No cutoff point for concordance between the authors was employed. Subjective consensus was established to form the categories of analysis in this review.

\section{Demographic \& cultural variables}

Cultural and demographic variables were analyzed in depth in six studies (16\%). 1,25,28,29,36,41 Age was among the most frequently explored demographic characteristics explored: five articles ${ }^{1,25,28,29,41}$ analyzed the effect of this variable on IGT performance. Only one of these studies ${ }^{25}$ reported a significant difference in IGT net scores, with older adults (62.0 \pm 2.1 years old) showing higher net scores than the elderly $(79.6 \pm 3.3$ years old $)(t[18]=3.34, p=$ $0.04, d=1.52$ ) - the difference occurred only in decisionmaking (IGT). One possible caveat for such difference relative to other studies is the limited sample analyzed ( $\mathrm{n}$ $=10$ ). While two studies 28,41 found no differences in IGT net scores, both pointed to differences in the learning process in the different age groups tested (young/old, $p=0.026^{28}$; and young [25.5 \pm 4.7 years old] vs. elderly $[67.4 \pm 5.2$ years old $\left.], p=0.021^{41}\right)$. Another study ${ }^{1}$ found no differences in either net scores or the learning process.

One study analyzing age and country of origin ${ }^{29}$ found that, even though there was no interaction between the two variables, there was a significant influence of culture (country of origin) on IGT net scores (country, $p \leq 0.001$; age, $p=0.134$; country vs. age, $p=0.291$ ).

Only one study emphasized gender differences, but it was included in the medical/clinic category because its key topic was frontal stroke. The authors stated that gender differences should be considered when planning psychotherapy and cognitive rehabilitation for frontal stroke patients. ${ }^{37}$ In total, the 36 studies analyzed 1,004 men $(39.97 \%)$ and 1,508 women $(60.03 \%)$.

Only one article ${ }^{36}$ focused on education as the main topic of research. The authors reported no significant differences in IGT net scores between groups with high $(9.15 \pm 25.7)$ and low $(9.00 \pm 16.46)$ education levels 
$(p=0.98)$. This finding corroborates the still scarce international scientific literature about the topic, which seems to converge to the conclusion that schooling does not significantly influence performance on IGT. ${ }^{42-44}$

\section{Psychiatry \& personality}

This appeared to be the most productive topic in empirical IGT studies in Brazil, with 14 scientific publications (39\%). ${ }^{7-20}$ The studies addressed personality and psychiatry disorders as well as addictions and substance abuse. Some studies also analyzed genetic components of psychiatric disorders.

Four studies ${ }^{11-14}$ examined OCD, given their neuroanatomical focus on regions known to contribute to successful IGT performance, including the orbitofrontal cortex. ${ }^{45}$ These studies reported controversial results for IGT performance and little similarities in targeted genetic markers of disease. For example, one study involving 107 individuals with $\mathrm{OCD}^{13}$ found impaired performance on the IGT net scores of these patients $(-4.96 \pm 12.85)$ when compared to healthy controls $(6.42 \pm 21.88$; $p<$ $0.01)$, whereas another study ${ }^{12}$ did not find differences between patients with OCD and healthy controls.

When incorporating genetic information, a subgroup of OCD patients (those with $\mathrm{S}$ and/or LG alleles) exhibited low performance on the IGT. ${ }^{11}$ Participants of the high expressing group performed significantly better on the third, fourth, and fifth blocks and also on total net scores. That study was the first to demonstrate a significant association between 5-HTTLPR and decisionmaking processes in OCD patients. Another study investigating individuals with $O C D$ who were carriers of the dominant form of the BDNF gene ${ }^{14}$ found deficits in the initial blocks of the IGT, suggesting that the deficits in these individuals were related to decision-making in ambiguous situations only, where there was no clear indicative of the consequence associated with the choice.

Several of the other studies under the psychiatry \& personality domain focused on $\mathrm{BD}^{8-10}$ given its neuroanatomical link to the inferior prefrontal cortex and subcortical structures known to facilitate IGT performance. ${ }^{46}$ One study ${ }^{8}$ reported significant differences between clinical groups and controls $(z=-4.63, p=0.0001)$. Notwithstanding, it did also report that a positive history of past suicide attempt(s) was predictive of worse IGT net scores as well as worse performance in block 3 when compared to individuals with $B D$ and a negative history of suicide attempts. Another study ${ }^{9}$ reported significant differences between clinical cases and controls in net score (20.57 \pm 23.61 vs. $24.28 \pm 3.89, z=-4.56, p<0.001)$, which also correlated with a positive history of suicide attempt(s). Another study ${ }^{10}$ assessed GAD associated with $B D$ vs. BD alone and found no significant differences between the clinical groups in terms of net scores $(z=$ $-1.15, \mathrm{p}=0.251$ ).

Another well-developed axis of psychiatry \& personality studies has been the area of addiction, particularly drug and alcohol abuse. ${ }^{15-18}$ One study ${ }^{19}$ assessed internet addiction, given the overlapping reward circuitry impairments implicated in these disorders. ${ }^{47}$ The four studies of drug and alcohol abuse indicated a significant difference favoring advantageous decision-making in controls vs. those with addiction on IGT net score classifications. One study $^{15}$ indicated that alcoholics in abstinence for $\leq 120$ days differed from controls in net scores $(1.03 \pm 6.14$ vs. 10.19 $\pm 22.7, z=-3.70, p=0.0001)$. Another study ${ }^{16}$ reported that crack/cocaine dependents in abstinence for 2 weeks made more disadvantageous choices on the IGT when compared with a control group of 15 healthy individuals (volunteers recruited in the city of São Paulo), and these results were correlated with a higher level of social dysfunction according to the Social Adjustment Scale Self-Report (SAS-SR) in crack/cocaine users. Finally, in the study ${ }^{19}$ about internet addiction, one of the two cases analyzed displayed an impaired performance on the IGT.

Two other studies ${ }^{3,7}$ approached impulsivity. The first study ${ }^{7}$ focused on impulsivity as it pertains to adults with ADHD. Significant correlations were found between self-reported impulsivity in the ADHD group (Barratt Impulsiveness Scale, BIS-11) and performance on the IGT. ${ }^{48}$ Another report of $\mathrm{ADHD}^{3}$ found that a group of 25 individuals with the disorder had significantly different IGT net scores compared to groups of healthy controls (25 healthy volunteers with proficiency in English $=21.28 \pm 23.15$ vs. 25 healthy volunteers without proficiency in English = $21.13 \pm 21.99$ vs. $A D H D$ group $=5.01 \pm 23.93 ; F=9.323$, $p=0.0001$ ). It should be noted, however, that the IGT version in question was a cultural adaptation, and not the original IGT (this study was included in the psychometric properties \& test administration standardization category, please refer to it for more details).

Of note, one study investigated borderline personality disorder in a case report. A 27 year-old man with this disorder had his performance compared with asymptomatic male controls matched for age and years of education. The criterion for altered results was a 2 standard deviation difference between the patient's score and the healthy controls. According to the authors, the patient made more non-profitable choices on the IGT, suggesting deficits in decision-making. ${ }^{20}$

\section{Medical/clinic}

Health-related issues were analyzed in 11 publications $(31 \%)^{21,23,26,30,32-35,37,38,40}$ and covered a variety of neurological 
issues. Three studies ${ }^{23,37,38}$ focused on stroke and its impact on decision-making, with one study addressing treatment implications. One of these studies focused on the impact of right vs. left hemisphere stroke, ${ }^{38}$ reporting that both types of patients achieved an adequate performance on the IGT. Another study ${ }^{37}$ addressed the effects of frontal stroke and gender on decision-making. While IGT results did not differ significantly between men and women, both groups showed a preference for risky choices (B cards) and failed to show consistent learning during the task. The only significant sex difference between groups was related to total BIS$11 \operatorname{scores}^{48}(\mathrm{U}=15.5, \mathrm{z}=-2.42, \mathrm{p}=0.013)$ and its nonplanning subscale $(U=18.0, z=-2.22, p=0.028)$. Data indicated a higher lack of planning (non-planning) among women. Lastly, the study addressing treatment ${ }^{23}$ examined cognition and behavior before and after the administration of methylphenidate in a patient with anterior communicant artery aneurysm. The first neuropsychological assessment was performed 48 months after stroke, after which the administration of methylphenidate ( $40 \mathrm{mg} /$ day) was begun, followed by another neuropsychological assessment with the same instruments but another version of the IGT (win IGT/lose IGT) ${ }^{43} 6$ months later. Methylphenidate improved executive functions, attention, and decision-making abilities. Performance on the IGT varied from pre-treatment levels (win IGT, 1st assessment net score $=-8$ vs. lose IGT, 2nd assessment net score $=7$ ).

Another study ${ }^{30}$ addressed three cases of dysexecutive syndrome, two resulting from traumatic brain injury and the other due to developmental problems. Impairments on IGT performance were identified in all three cases.

Several studies appeared to be the only one of their kind conducted in Brazil, including an isolated study on mild cognitive impairment. An analysis of older adults with and without mild cognitive impairment found no differences in IGT net scores but suggested an impaired learning during IGT in individuals with MCI. ${ }^{26}$ These results, however, are implied, as the authors did not describe the statistical results of their repeated-measures analysis of variance, but rather preferred to graphically display the differences between groups. Likewise, in a study investigating temporal lobe epilepsy, the authors did not report IGT testing results. ${ }^{33}$

Despite being an isolated report, a recent publication on cognitive impairment due to subclinical hypothyroidism ${ }^{32}$ had the largest sample $(n=267)$ of all Brazilian IGT studies. The study reported differences in cognitive flexibility measured by the WCST and in sustained attention measured by the CPT-II (omission errors), but IGT scores (net score and blocks) showed no statistically significant differences between those with and without subclinical hypothyroidism. Another study ${ }^{21}$ investigating impulsivity and genetics failed to find a relationship between genetic polymorphism 5-HTTLPR and decision-making (considered by those authors as equivalent to cognitive impulsivity) based on IGT net scores in 127 individuals ( $\mathrm{t}[73]=0.63, \mathrm{p}=0.87$ ).

General health issues were analyzed in three publications. $34,35,40$ They focused mainly on motor control as determined in sports, including technical fouls and impulsivity in female handball. The study ${ }^{40}$ focused on the relationship between different facets of impulsivity and the motor control of aiming movements. They concluded that motor impulsivity (measured by the CPT-II) is more related to motor control than cognitive impulsivity (measured by the IGT). They also stated that IGT net scores were used as a dependent measure of cognitive (decision-making) impulsivity. Unlike CPT-II scores, high scores on the IGT indicated a low level of impulsivity.

One study ${ }^{34}$ relating motor performance and non-planning impulsivity did not find any significant correlations. Another study ${ }^{35}$ found a significant correlation between performance on the IGT and offensive technical fouls committed by female handball players in 11 matches. These studies (especially the former ${ }^{34}$ ) concluded that the impact of motor impulsivity is greater than the impact of cognitive impulsivity on motor control.

\section{Psychometric properties \& test administration standardization}

The psychometric properties of IGT and its administration standardization were analyzed in five Brazilian studies (14\%). 3,24,27,31,39 Several studies, $3,24,27$ focused on changes in task administration, the majority of which - not surprisingly - found significant differences in performance results when comparing the changed task with the original IGT. In one study, ${ }^{24}$ the authors varied the amount of monetary feedback given over the course of the task. In another, ${ }^{27}$ visual feedback cues were altered: even though there were no differences in the mean number of cards selected from each deck between the changed and the original IGT, there were significant differences in risk aversion, with alterations in visual cues resulting in better sensibility to loss frequency and a less risky behavior than that seen in the original IGT $(F[5.85]=1, p=0.02)$.

The last study ${ }^{3}$ addressed the adaptation of the IGT to Brazilian Portuguese by a research group from UFMG, in Minas Gerais, southeastern Brazil. The goals were to describe the cross-cultural adaptation process and to assess the discriminant validity of the resulting version. The authors applied the original IGT (English version) to a group of healthy volunteers proficient in English, and 
the IGT-BR (Brazilian adapted version) to two groups, one with healthy volunteers not proficient in English and another with ADHD patients not proficient in English. No differences between the two first groups (healthy volunteers) were found, with similar outcomes for the original English version and the Brazilian adaptation. The translation of the IGT was also discussed in that study. The authors found a kappa coefficient (Cohen) of $k=0.8$ 1 , indicating that the translation was appropriate. Based on these data, the authors concluded that the adapted IGT-BR version was adequate.

Other studies ${ }^{31,39}$ addressed test-retest reliability and construct validity of the IGT. Test-retest results ${ }^{31}$ pointed to a positive, significant correlation in net scores between time 1 and time 2 (with intervals ranging from 1 to 6 months), with a linear Pearson coefficient of $r=$ 0.43 ( $p=0.002$ ). Construct validity ${ }^{39}$ was assessed by correlating IGT scores with other executive function tasks, including the WCST, the Trail Making Test (TMT), and the Hayling Test. Of these, only the Hayling Test (time part B) correlated with IGT performance, suggesting a direct relationship between inhibition speed and advantageous decision-making.

\section{Discussion}

The IGT is the task most widely used to evaluate the process of decision-making. ${ }^{3}$ It was first adapted to Brazilian Portuguese in 2006, ${ }^{1}$ and then again in 2008, ${ }^{3}$ by different research groups, leading to the generation of two regionalized versions. Following the expansion in decision-making neuroscientific research using the IGT, this assessment tool has been used in a wide variety of studies. We conducted a systematic review of empirical research conducted in Brazil with the IGT to provide the reader with a brief overview of current studies and to discuss directions for future research.

This review revealed a focus of Brazilian-based IGT studies on clinical populations with neuropsychiatric and personality disorders, which can probably be explained by the fact that the IGT is considered one of the few instruments sensitive to specific (ventromedial/orbito) frontal deficits, and many of the studies in psychiatry have focused on populations with such prefrontal involvement. ${ }^{4,28}$ In fact, orbitofrontal cortex neural networks located in the prefrontal cortex are key circuits to both the cognitive process of decision-making and the regulation of social behavior. ${ }^{20}$ Insults to this part of the cortex are associated with the onset of several behavioral disorders, including OCD and substance abuse, both of which show a negative impact on decision-making. ${ }^{15-18}$ In continuing these applications to the field of mental health diagnosis, genetic vulnerabilities and treatment outcomes may prove promising fields of psychiatric research in Brazil.

Demographic variables were also analyzed rather intensively in Brazilian IGT studies. One of the main variables of interest was age. Findings on the effect of aging on decision-making remains controversial, hindering the development of a consensus on the issue. One possible explanation for this discrepancy is the fact that age groups and healthy aging criteria used while composing samples have not been fully explored. Given the complex array of factors involved in aging, ${ }^{49}$ including vascular risk and subclinical depression, ${ }^{50}$ much work needs to be done before we can understand the impact of these variables on aging and decision-making in Brazil. Additionally, cognitive aging does not follow a linear trend; concepts such as neuroplasticity, cognitive reserve, and compensation can have different impacts on the aging population. Future studies should consider these aspects of aging when assessing IGT performance, but will require large sample sizes to enable robust conclusions. Given the impact that decision-making has on the autonomy and protection of older people, expert knowledge on the neuropsychology of aging and decision-making will become increasingly important as the Brazilian population of older adults increases.

Some cultural factors beyond aging were also addressed in Brazilian IGT studies, e.g., the impact of education on decision-making. ${ }^{3,29,36}$ As expected, individuals with lower education levels performed worse on the IGT than those with higher levels of education; however, these results are from one study only and need replication and additional work. The concern with tailoring the IGT to our country and to regional cultural differences will only add assessment accuracy via crosscultural adaptation. In additional to regional validity, other psychometric properties were also verified, ${ }^{31}$ such as test-retest reliability and construct validity, but these results also await replication. Research on the psychometric properties of the IGT will become increasingly important, especially if research on this task in Brazil is to further incorporate the theoretical model of the somatic marker hypothesis. ${ }^{51}$

It is worth noting that the majority of IGT studies conducted in Brazil continue to take place in the same geographic locations that originally adapted the task for use in Brazil, i.e., the southern and southeastern regions of Brazil. This indicates the need for an increased dissemination of the IGT task and its use in other Brazilian states through scientific cooperation between research centers. Such increased collaboration would lead to a more precise picture of the population parameters that influence decision-making through larger sample sizes 
and greater access to patient populations via multisite studies of particular disorders. Thinking about the national future of decision-making research, studies should publish detailed results including statistical findings and group means whenever possible. This will assist other Brazilian investigators in i) conducting power calculations to determine adequate sample sizes for their own work; ii) determining which version of the IGT task was used in individual studies; and iii) determining how results obtained for net scores and task blocks may play out in their own studies. Greater transparency in published IGT data will also allow for future meta-analyses in this area and hopefully lead to a higher degree of consensus in results across clinical populations.

Incorporating a larger neuropsychological test battery into the study of IGT performance in Brazil is also desirable in future studies. Sixteen studies ${ }^{7-11,13-15,19-21,30,32,34,35,40}$ incorporated the CPT-II and found significant associations between the two tasks. This suggests common cognitive constructs involving impulsivity in attentional and motor dimensions in both the IGT and the CPT-II. Studies conducted in Brazil appear to provide support for a convergence of Bechara's concept of cognitive impulsivity ${ }^{42}$ and Barratt's concept of non-planning impulsivity. ${ }^{48}$ Bechara's model proposes a functional and structural difference between motor impulsivity, which would be related to inhibition of pre-potent responses, and decisionmaking, which in one instance has also been referred to as cognitive impulsivity. This conceptualization seems to be analogous to Barratt's non-planning impulsivity concept, because both models consider the tendency to act with less forethought (i.e., in the decision-making context, IGT measures the preference for long-term advantageous choices vs. more short-term disadvantageous choices, and the BIS-11 non-planning subscale measures the lack of 'futuring'). A more detailed discussion on this topic is available elsewhere. ${ }^{7}$ Given the applicability of IGT as a measure of cognitive impulsivity related to impulsivity in the sporting arena, Brazilian scientists may be in a unique position to delve further into the convergence of cognitive and motor impulsivity using the IGT and real-world situations of reward and punishment. ${ }^{34,35,40}$ In the future, the growing amount of studies analyzing the implications of motor control and decision-making in the sports arena could potentially create the fifth independent category of the IGT scenario: decision-making in sports, covering some of the studies currently in the general health branch of research.

Another neuropsychological instrument frequently associated with the IGT was the WCST, in 12 studies. $8,12,15-17,26,30,32,33,36,37,39$ Even though correlations between the two instruments appear to be weak (e.g., perseverative WCST errors vs. performance on the first block of the IGT), investigators ${ }^{39}$ have suggested that this relationship remains inconclusive. While the IGT is considered a classical instrument in the evaluation of high emotional influence and the WCST has a higher preponderance of low emotional influence, ${ }^{26,52}$ additional work using more tasks of high and low emotional as well as executive influence are needed to confirm this tentative association in the IGT literature.

As neuropsychological IGT research advances in Brazil, the goal should be to address weaknesses of previous studies and to generate normative data that is culturally compatible ${ }^{29}$ with this country. For example, on the one hand, the IGT is a computerized instrument; on the other, much of the IGT work conducted in Brazil focuses on the elderly. Not every elder has access to or familiarity with computers; this should be considered in future works on aging. A suggestion for such studies would be the preliminary survey of the participants' familiarity with the use of personal computers.

Another relevant issue for future research is the use of neuroimaging as a basic investigation tool. Only one isolated study ${ }^{20}$ ( $3 \%$ of the total sample) employed this resource (magnetic resonance imaging, MRI) in decisionmaking investigation in Brazil, a limitation that is partly explained by the difficult access to this type of equipment. Few university laboratories currently have these devices, but we strongly recommend that future research should include neuroimaging, especially functional magnetic resonance imaging (fMRI), as the somatic marker hypothesis itself was based on neuroimage validity convergence. ${ }^{5}$ This improvement will also underscore the need to employ more advanced statistics in the studies, with voxelmetrics and multivariate data modeling techniques to better evaluate cognitive neurobiological findings using IGT. Furthermore, another important resource, still underemployed in decision-making studies in Brazil, is genotyping. Only four studies ${ }^{9,11,14,21}$ ( $11 \%$ of the total sample) described genetic data. The continuous and fast advance observed in genetics, studying how individual variations in hormones and genes can influence reward processing and decision-making is at the top of the agenda for future research. The development of more robust experiments that can address some of the weak points in the somatic marker hypothesis, ${ }^{51}$ as well as further explore the construct of decision-making, ${ }^{6}$ will be most welcome.

The trend observed in the course of this review regarding IGT publication history in Brazil indicates a strong increase in decision-making research using this task in recent years. With interest and productivity on the rise, it is our hope that awareness of the strengths and weaknesses of previous work here highlighted, the humble suggestions made for future research, and 
an increased collaboration across research centers will strengthen Brazil's position in the IGT research community and continue to build knowledge in this important area of research in the coming years.

\section{Acknowledgments}

To Rochele Paz Fonseca (Pontifícia Universidade Católica do Rio Grande do Sul, PUCRS) and Leandro Fernandes Malloy-Diniz (UFMG) for their invaluable contribution providing articles, suggestions, and revising the preliminary list of articles selected for review.

\section{References}

1. Schneider DG, Parente MA. O desempenho de adultos jovens e idosos na Iowa Gambling Task (IGT): um estudo sobre a tomada de decisão. Psicol Reflex Crit. 2006;19:442-50.

2. Alves GS, Rosenthal M. Avaliação neuropsicológica dos circuitos pré-frontais relacionados à tomada de decisão na esquizofrenia: uma revisão sistemática da literatura. Rev Psiquiatr Rio Gd Sul. 2006;28:330-41.

3. Malloy-Diniz LF, Leite WB, Moraes PH, Corrêa H, Bechara A, Fuentes D. Brazilian Portuguese version of the Iowa Gambling Task (IGT): transcultural adaptation and discriminant validity. Rev Bras Psiquiatr. 2008;30:144-8.

4. Bechara A, Damasio AR, Damasio $H$, Anderson SW. Insensitivity to future consequences following damage to human prefrontal cortex. Cognition. 1994;50:7-15.

5. Damasio A. O erro de Descartes: Emoção, razão e cérebro humano. São Paulo: Companhia das Letras; 1996.

6. Yechiam E, Busemeyer JR, Stout JC, Bechara A. Using cognitive models to map relations between neuropsychological disorders and human decision making deficits. Psych Sci. 2005; 16:973-8.

7. Malloy-Diniz LF, Fuentes D, Leite WB, Corrêa $H$, Bechara A. Impulsive behavior in adults with attention deficit hyperactivity disorder: characterization of attentional, motor and cognitive impulsiveness. J Int Neuropsychol Soc. 2007;13:1-6.

8. Malloy-Diniz LF, Neves FS, Abrantes SS, Fuentes D, Corrêa H. Suicide behavior and neuropsychological assessment of type I bipolar patients. ] Affect Disord. 2009;112:231-6.

9. Malloy-Diniz LF, Neves FS, Moraes PH, De Marco LA, RomanoSilva MA, Krebs $M$, et al. The 5-HTTLPR polymorphism, impulsivity and suicide behavior in euthymic bipolar patients. J Affect Disord. 2011;133:221-6.

10. Couto TC, Neves FS, Machado MC, Vasconcelos AG, Corrêa H, Malloy-Diniz LF. Assessment of impulsivity in bipolar disorder (BD) in comorbidity with generalized anxiety disorder (GAD): revisiting the hypothesis of protective effect. Clin Neuropsychiatry. 2012;9:102-6.

11.Rocha FF, Malloy-Diniz LF, Lage NV, Romano-Silva MA, De Marco LA, Corrêa H. Decision-making impairment is related to serotonin transporter promoter polymorphism in a sample of patients with obsessive-compulsive disorder. Behav Brain Res. 2008;195:159-63.

12. Borges MC, Braga TD, Iêgo S, D'alcante CC, Sidrim I, Machado MC, et al. Cognitive dysfunction in post-traumatic obsessive-compulsive behaviour. Aust N Zeal J Psychiatry. 2011;45:76-85.
13. Rocha FF, Alvarenga NB, Malloy-Diniz LF, Corrêa H. Decisionmaking impairment in obsessive-compulsive disorder as measured by the Iowa Gambling Task. Arq Neuropsiquiatr. 2011;69:642-7.

14. Rocha FF, Malloy-Diniz LF, Lage NV, Corrêa H. The relationship between the Met allele of the BDNF Val66Met polymorphism and impairments in decision making under ambiguity in patients with obsessive-compulsive disorder. Genes Brain Behav. 2011;10:523-9.

15. Salgado JV, Malloy-Diniz LF, Campos VR, Abrantes SS, Fuentes D, Bechara A, et al. Avaliação neuropsicológica do comportamento impulsivo de sujeitos dependentes de álcool em abstinência. Rev Bras Psiquiatr. 2008;31:4-9.

16. Cunha PJ, Bechara A, Andrade AG, Nicastri S. Decision-making deficits linked to real-life social dysfunction in crack cocainedependent individuals. Am J Addiction. 2011;20:78-86.

17. Gonçalves HA, Cardoso CO, Araújo RB. Funções executivas na dependência de crack: um estudo de caso. Rev Neuropsicol Latinoam. 2011;3:7-13.

18. Viola TW, Cardoso CO, Francke ID, Gonçalves HA, Pezzi JC, Araújo RB, et al. Tomada de decisão em dependentes de crack: um estudo com o Iowa Gambling Task. Estud Psicol. 2012;17:99-106.

19. Coutinho G, Mattos P, Miele F, Borges $M$. The cognitive profile and different presentations of internet addiction in teenagers: two case reports. Clin Neuropsychiatry. 2010;7:164-9.

20. Rocha FF, Malloy-Diniz LF, de Souza KC, Prais HA, Correa H, Teixeira AL. Borderline personality features possibly related to cingulate and orbitofrontal cortices dysfunction due to schizencephaly. Clin Neurol Neurosurg. 2008;110:396-9.

21. Lage GM, Malloy-Diniz LF, Matos LO, Bastos MA, Abrantes SS, Corrêa H. Impulsivity and the 5-HTTLPR polymorphism in a non-clinical sample. PLoS One. 2011;6:e16927.

22. Shiv B, Bechara A, Lewin I, Alba JW, Bettman JR, Dube L, et al. Decision neuroscience. Mark Lett. 2005;16:375-86.

23. Leite WB, Malloy-Diniz LF, Corrêa $H$. Effects of methylphenidate on cognition and behaviour: ruptured communicant aneurysm of the anterior artery. Aust N Zeal J Psychiatry. 2007;41:555-6.

24. Schneider DG, Wagner GP, Denburg N, Parente MA. Iowa Gambling Task: administration effects in older adults. Dement Neuropsychol. 2007;1:66-73.

25. Bakos DS, Couto MC, Melo WV, Parente MA, Koller SH, Bizarro L. Executive functions in the young elderly and oldest old: a preliminary comparison emphasizing decision making. Psychol Neurosci. 2008;1:183-9.

26. Wagner GP, Trentini CM, Parente MA. O Desempenho de idosos com e sem declínio cognitivo leve nos testes Wisconsin de classificação de cartas e Iowa Gambling Task. PSICO. 2009;40:220-6.

27. Wagner GP, Parente MA. O desempenho de idosos quanto a tomada de decisão em duas variações do IGT. Psic Teor Pesq. 2009;25:425-33.

28. Bakos DS, Parente MA, Bertagnolli AC. A tomada de decisão em adultos jovens e em adultos idosos: um estudo comparativo. Psicol Cienc Prof. 2010;30:162-73.

29. Bakos DS, Denburg NL, Fonseca RP, Parente MA. A cultural study on decision making performance differences on the Iowa Gambling Task between selected groups of Brazilians and Americans. Psychol Neurosci. 2010;3:101-7.

30. Borges M, Coutinho G, Miele F, Malloy-Diniz LF, Martins R, Rabelo B, et al. Síndromes disexecutivas do desenvolvimento e adquiridas na prática clínica: três relatos de caso. Rev Psiquiatr Clin. 2010;37:285-90.

31. Cardoso CO, Carvalho JC, Cotrena C, Bakos DG, Kristensen $\mathrm{CH}$, Fonseca RP. Estudo de fidedignidade do instrumento neuropsicológico Iowa Gambling Task. J Bras Psiquiatr. 2010;59:279-85. 
32. Fernandes RS, Alvarenga NB, Silva TI, Rocha FF. Disfunções cognitivas em pacientes com hipotireoidismo subclínico. Arq Bras Endocrinol Metab. 2011;55:224-8.

33. Gois J, Valente K, Vicentiis S, Moschetta S, Kuczynski E, Fiore $\mathrm{L}$, et al. Assessment of psychosocial adjustment in patients with temporal lobe epilepsy using a standard measure. Epilepsy Behav. 2011;20:89-94.

34. Lage GM, Malloy-Diniz LF, Fialho JV, Gomes CM, Albuquerque MR, Corrêa H. Correlação entre as dimensões da impulsividade e o controle em uma tarefa motora de timing. Braz J Motor Behav. 2011;6:39-46.

35. Lage GM, Gallo LG, Cassiano GJ, Lobo IL, Vieira MV, Salgado $\mathrm{JV}$, et al. Correlations between impulsivity and technical performance in handball female athletes. Psychology. 2011;2:721-6.

36. Carvalho JC, Bakos DS, Cotrena C, Kristensen CH, Fonseca RP. Tomada de decisão no IGT: comparação quanto a variável escolaridade. RIDEP. 2011;32:171-86.

37. Scheffer M, Monteiro JK, Almeida RM. Frontal stroke: Problem solving, decision making, impulsiveness and depressive symptoms in men and women. Psychol Neurosci. 2011;4:267-78.

38. Cardoso CO, Kristensen $\mathrm{CH}$, Carvalho JC, Gindri G, Fonseca RP. Tomada de decisão no IGT: estudo de caso pós-avc de hemisfério direito versus esquerdo. Psico-USF. 2012;17:11-20.

39. Carvalho JC, Cardoso CO, Cotrena C, Bakos DS, Kristensen C, Fonseca RP. Tomada de decisão e outras funções executivas: um estudo correlacional. Cien Cogn. 2012;17:94-104.

40. Lage GM, Malloy-Diniz LF, Neves FS, Moraes PH, Corrêa H. A kinematic analysis of the association between impulsivity and manual aiming control. Hum Movement Sci. 2012;31:811-23.

41. Carvalho JC, Cardoso CdeO, Schneider-Bakos D, Kristensen $\mathrm{CH}$, Fonseca RP. The effect of age on decision-making according to the Iowa Gambling Task. Span J Psychol. 2012;15:480-6.

42. Bechara A, Damasio H, Damasio AR. Emotion, decision and the orbitofrontal cortex. Cereb Cortex. 2000;10:295-307.

43. Bechara A, Tranel D, Damasio H. Characterization of the decision-making deficit of patients with ventromedial prefrontal cortex lesions. Brain. 2000;123:2189-202.
44. Fry Y, Greenop K, Tunrbull O, Bowman C. The effect of education and gender on emotion-based decision-making. S Afr J Psychol. 2000;39:122-32.

45. Maia TV, Cooney RE, Peterson BS. The neural bases of obsessive-compulsive disorder in children and adults. Dev Psychopathol. 2008;20:1251-83.

46. Strakowski SM, Delbello MP, Adler CM. The functional neuroanatomy of bipolar disorder: a review of neuroimaging findings. Mol Psychiatry. 2005;10:105-16.

47. Goldstein RZ, Volkow ND. Drug addiction and its underlying neurobiological basis: Neuroimaging evidence for the involvement of the frontal cortex. Am J Psychiatry. 2002; 159:1642-52.

48. Patton JH, Stanford MS, Barratt ES. Factor structure of the Barratt Impulsiveness Scale. J Clin Psychol. 1995;51:768-74.

49. Drag LL, Bieliauskas LA. Contemporary review 2009: cognitive aging. J Geriatr Psichychiatry. 2010;23:75-93.

50. Lamar M, Charlton RA, Morris RG, Markus HS. The impact of subcortical white matter disease on mood in euthymic older adults: a diffusion tensor imaging study. Am J Geriatr Psychiatry. 2010;18:634-42.

51. Dunn BD, Dalgleish T, Lawrence AD. The somatic marker hypothesis: a critical evaluation. Neurosci Biobehav Rev. 2006;30:239-71.

52. Krain AL, Wilson AM, Arbuckle R, Castellanos FX, Milham MP. Distinct neural mechanisms of risk and ambiguity: A metaanalysis of decision-making. Neuroimage. 2006;32:477-84.

\section{Correspondence}

André Figueiras Rutz

R. Marechal Deodoro, 430/63, Centro

80010-010 - Curitiba, PR - Brazil

Tel.: +55 (41) 9993.6886

E-mail: rutzaf@gmail.com 